\title{
Desalination Engineering: Environmental Impacts of the Brine Disposal and Their Control
}

\author{
Djamel Ghernaout ${ }^{1,2}$ \\ ${ }^{1}$ Chemical Engineering Department, College of Engineering, University of Ha'il, Ha'il, Saudi Arabia \\ ${ }^{2}$ Chemical Engineering Department, Faculty of Engineering, University of Blida, Blida, Algeria \\ Email: djamel_andalus@hotmail.com
}

How to cite this paper: Ghernaout, D (2020) Desalination Engineering: Environmental Impacts of the Brine Disposal and Their Control. Open Access Library Journal, 7: e6777.

https://doi.org/10.4236/oalib.1106777

Received: September 3, 2020

Accepted: September 26, 2020

Published: September 29, 2020

Copyright $\odot 2020$ by author(s) and Open Access Library Inc.

This work is licensed under the Creative

Commons Attribution International

License (CC BY 4.0).

http://creativecommons.org/licenses/by/4.0/

\section{(c) (i) Open Access}

\begin{abstract}
Freshwater supplies remain more and more in lack corresponding to the increased demand for several human activities. Such difficult circumstances make desalination of saline water an obligation. Desalination to take out water from saline water has been proved as a safe non-traditional water supply. Nevertheless, like any human-founded method, desalination has conducted to several influences on nature. Charged with chemical products, brine is discharged back to nature. Greenhouse gases (GHGs) emissions are liberated to the atmosphere. Brine and GHGs are the most important effects that have been broadly investigated with some attempts accorded to their mitigation and control strategies (M\&CSs). This review examines the M\&CSs related to the several environmental impacts (EIs) of desalination engineering and focuses on brine disposal. Numerous EIs could be avoided, or at least reduced, by integrating specific design standards and ameliorating applied technologies. The feedwater source possesses a considerable influence on EIs. At the identical degree, desalination engineering possesses an important impact on the EIs linked to brine features and energy consumption. Fresh desalination techniques have depicted decreased EIs relative to traditional thermal and membrane desalination methods. Further, employing renewable and waste energy sources has illustrated a considerable decrease in EIs related to energy consumption.
\end{abstract}

\section{Subject Areas}

Chemical Engineering \& Technology

\section{Keywords}

Brine Disposal, Desalination, Seawater, Brackish Water, Mitigation and 


\section{Introduction}

Being vital to all manifestations of life, water is an essential resource [1]. Nevertheless, not all water resources obtainable on and in the Earth are easily available for use [2]. Freshwater resources, which are available to use thanks to their low salinity, form only $2.5 \%$ of the total water existing on/in the Earth [3]. Only $30 \%$ of total freshwater is potable (i.e., $0.75 \%$ of the total water on Earth) with $70 \%$ as inaccessible resources in the form of glaciers and snowcaps, $30 \%$ as groundwater, and $0.27 \%$ as surface water [1]. Saline water constitutes almost $97.5 \%$ of the total water existing on Earth. It is attainable to nearly all nations; rendering desalination the indispensable choice for securing water supply for water-stressed nations [4]. The present universal desalination capacity (UDC) is nearly 100 million cubic meters per day (MCM/d) from around 16 thousand plants in 175 states around the globe, with the middle east and north Africa (MENA) countries holding around $50 \%$ of the UDC [5] [6].

Thermal desalination employing multistage flash distillation (MSF) and multi-effect distillation (MED) has been the principal desalination technique over the 1950s-1970s period [1]. Thermal desalination is chosen for power and water production (i.e., co-generation) and where energy is low cost [7]. Presently, thermal desalination accounts for around $25 \%$ of the UDC. Thermal desalination remains largely implemented in the Gulf Cooperation Council (GCC) countries [5]. Membrane desalination utilizing reverse osmosis (RO) and nanofiltration (NF) membranes has been developed in the 1970s-1980s [8] [9] [10]. Actually, $\mathrm{RO}$ and NF prevail in the desalination market thanks to their lower energy consumption and modular nature [5] [11].

Thermal desalination possesses the benefit of being appropriate for some circumstances like high-salinity, high-temperature, and low-quality feedwaters [1] [12]. Nevertheless, the prime drawbacks stay the high-energy consumption(thus higher cost) and higher environmental impacts (EIs).Greater EIs are mostly due to greenhouse gases (GHGs) emissions and discharge of hot brine [13] [14]. Otherwise, membrane desalination possesses the merits of lower energy consumption, and (thus lower cost), suitability to a wide range of feedwater salinity (such as wastewater, both domestic and industrial, brackish groundwater, and seawater), and plant size scalability (from few $\mathrm{m}^{3} / \mathrm{d}$ to hundreds of thousands $\mathrm{m}^{3} / \mathrm{d}$ ) [15]. In membrane desalination, the two major different methods of RO and NF furnish larger options for feedwater salinity. This is mostly attributed to the distinction in salt rejection with around $99.5 \%$ for RO, whilst it changes for NF from $50 \%$ to $90 \%$ for mono-valent ions such as $\mathrm{Na}^{+}$and $\mathrm{Cl}^{-}$and up to $99.5 \%$ for divalent ions such as $\mathrm{Ca}^{2+}$ and $\mathrm{SO}_{4}^{2-}$. Accordingly, $\mathrm{RO}$ runs at high pressure up to 70 bars, while NF runs up to 20 bars [16]. Nevertheless, RO possesses higher pretreatment demands that are not appropriate for high feedwater salini- 
ties as the maximum attainable recovery decreases as the feedwater salinity increases. Further, RO remains more prone to scaling and fouling since it is a pressure filtration-based process [17].

Even if thermal and membrane desalination techniques possess an established solidity and engineering maturity, they possess numerous dares like the high-energy consumption in the situation of thermal desalination, and high pretreatment demands in the situation of membrane desalination, in addition to the several EIs [1] [18] [19]. Further to the thermal and membrane desalination techniques, there is a collection of novel and emerging desalination methods, which are presently under expansion. The major reasons for initiating such emerging desalination methods are lower energy consumption, lower desalination price, and several others [1] [16] [20].

Simultaneously with the augmented use of desalination techniques, their EIs have been the focus of attention. Mainly, the EIs are a function of the feedwater source (either seawater or brackish water) and desalination method being used (thermal or membrane desalination) [1] [21]. Taking into account that the seawater desalination (SWD) is taking $61 \%$ of the UDC, juxtaposed to $21 \%$ for brackish water desalination (BWD), the EI of SWD attracted most of the research concern [5] [22]. Large research projects have been carried out to assess and investigate the EIs of SWD elements like intake and outfall [23], feedwater pretreatment [24], brine disposal and management [25] [26] [27] and GHGs emissions [28]. For all that such comprehensive investigations for the EIs of desalination methods, few researches have been dedicated to the mitigation and control strategies (M\&CSs) of these influences [1]. Moreover, such researches were pointed to treat specific effects of fixed steps (for instance, intakes, or pretreatment, etc.). Nevertheless, until now, there is no investigation realized a rating of the numerous M\&CSs for all the steps and techniques implied in desalination [1].

Elsaid et al. [1] adopted a holistic approach to examining the M\&CSs of the numerous EIs of desalination engineering. The approach treats an intake-to-outfall discussion of the effects for each part in the desalination engineering, which is resumed in Figure 1 [1]. First, Elsaid et al. [1] started their discussion with seawater intake and outfall for SWD exploring its effects and mitigation strategies. Second, they examined feedwater pretreatment and diverse chemical products injected for SWD and BWD, investigating procedures to reduce its EIs via efficacious pretreatment and usage of green chemicals. Third, they focused on the desalination process choice and optimization of its effectiveness, along with the process ameliorations to mitigate the related EIs concerning SWD and BWD. The high-energy consumption of desalination technologies possesses a large set of EIs (mostly via related GHGs emissions like $\mathrm{CO}_{\mathrm{x}}, \mathrm{NO}_{\mathrm{x}}, \mathrm{SO}_{\mathrm{x}}$, and particulate matter (PM)) presenting a massive carbon footprint. Employing renewable energy sources, as well as efficient power production, constitutes an efficacious mitigation tool for the relevant EIs [1] [29].

Brine disposal remains a challenging desalination problem in general and BWD in particular [1] [13]. Strategies to relieve the EIs of brine disposal are 


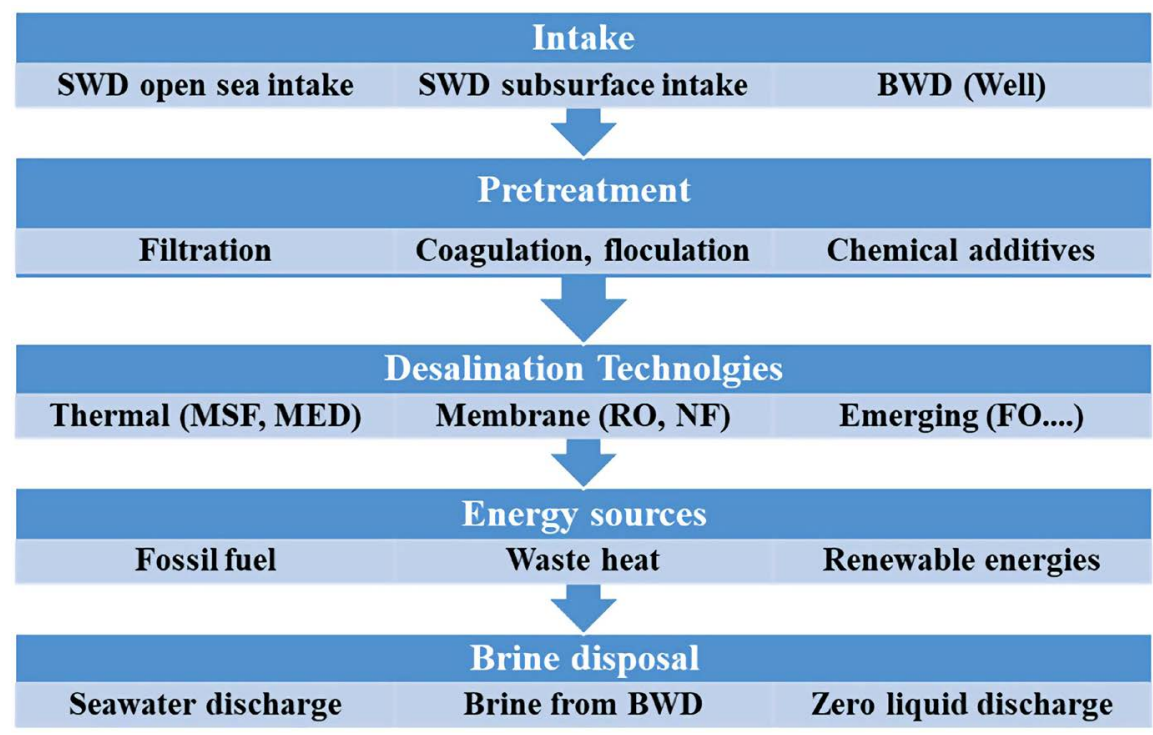

Figure 1. Outlines of the desalination engineering flow according to the intake-to-outfall approach [1].

greatly important because of its volume, representing about $142 \mathrm{MCM} /$ day, i.e., 1.5 times the desalination capability [5]. Compared to ambient seawater, brine ejected from desalination is characterized by bigger salinity and temperature; however, brine is as well carried with all the chemical agents being injected and different by-products being formed [1] [13] [25]. Strategies for relieving the EIs linked to brine disposal have attracted constant interest, with essays dedicated to suggesting a conclusive solution of zero liquid discharge for SWD and BWD [13] [30].

In this work, we present general recommendations to reduce the whole EIs of desalination engineering, with some successful situations to establish the performance of these M\&Cs strategies especially those for brine disposal. We start with a brief discussion of the main improvements in the field of desalination engineering.

\section{Desalination Engineering}

Desalination techniques are numerous and could be mostly categorized into two principal groups following technology maturity: developed and underdeveloped desalination techniques [1]. Developed and well-established techniques could be subdivided into thermal desalination and membrane desalination techniques. Such methods have been applied during decades with confirmed technical and economic feasibility and reliability. Emerging or underdeveloped desalination processes are those that are still at the pilot- or small-scale, with confirmed merits over presently utilized techniques in terms of energy consumption and/or broad feedwater quality. Some of such emerging techniques have been efficiently merged into a hybrid-mode to traditional desalination techniques to reach more advantages, like augmented recovery [31]. Figure 2 depicts the percentage desa 

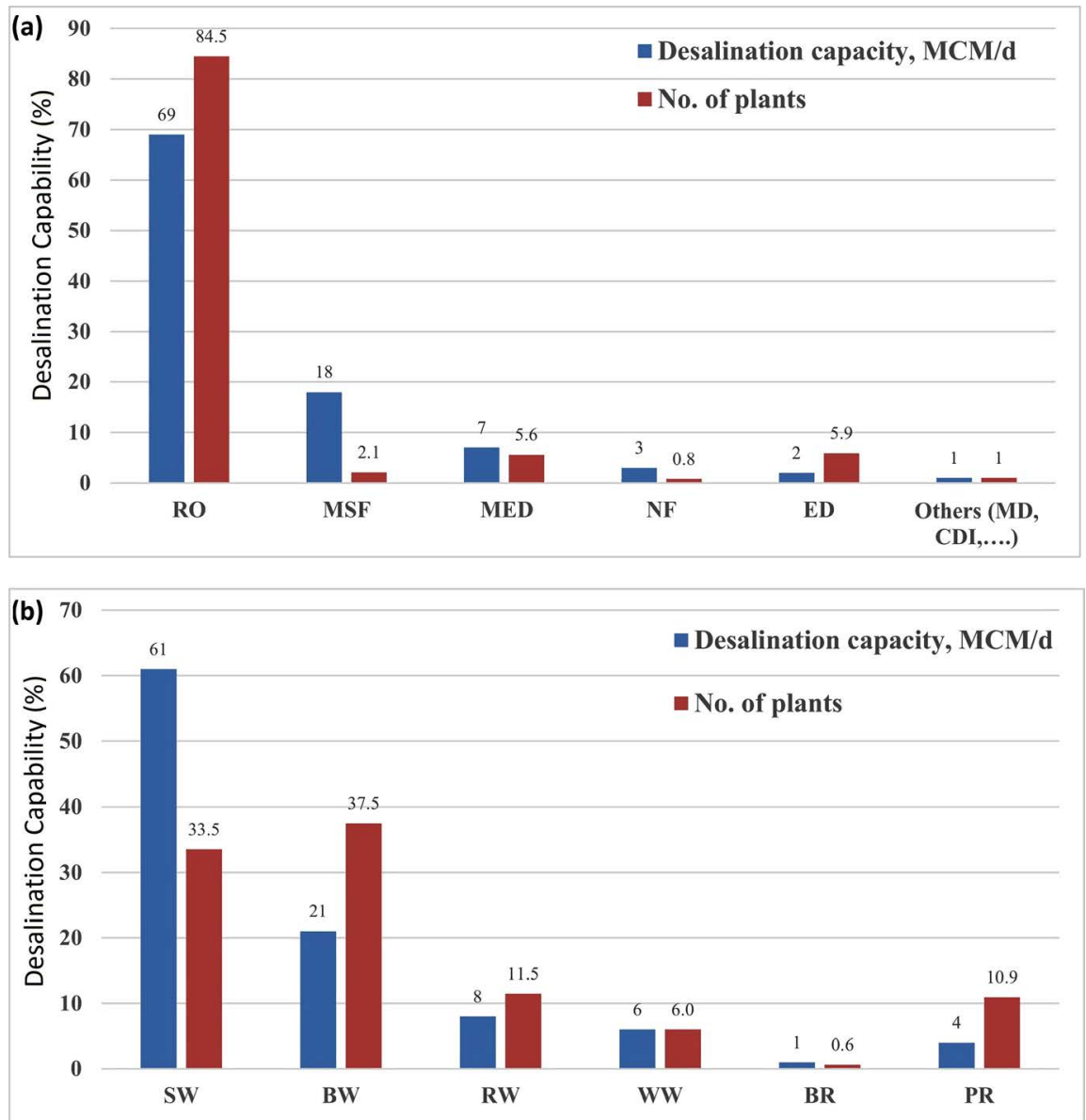

Figure 2. Portion of desalination capability and the number of plants following desalination technology (a) and feedwater source (b) (RO = reverse osmosis, MSF = multi-stage flash distillation, MED = multi-effect distillation, NF = nanofiltration, $\mathrm{ED}=$ electrodiyalysis, $\mathrm{SW}=$ seawater, $\mathrm{BW}=$ brackish water, $\mathrm{RW}=$ river water, $\mathrm{WW}=$ wastewater, $\mathrm{BR}=$ brine, $\mathrm{PR}=$ pure water) [5].

lination capability, which is about $100 \mathrm{MCM} / \mathrm{d}$, and the number of plants, around 16 thousand plants, the quota for each process, as well as feedwater source. SWD presents around $61 \%$ of UDC, pursued by $21 \%$ for BWD, comprising brackish groundwater, pursued by $8 \%$ for river water (RW), $6 \%$ for wastewater (WW), $1 \%$ for brine (BR), and finally $4 \%$ for pure water (PR) implementations [5].

\subsection{Thermal Desalination Methods}

Because the technique purely simulates the natural water cycle, thermal desalination is the earliest utilized method to acquire drinking water from saline water since ancient days [1] [6]. Since the method experiences phase change from liquid to vapor and then reversely from vapor to liquid, thermal desalination is occasionally named phase-change desalination. The method is thermal energy forced, in which the energy in the form of heat is furnished to push the vaporization of a fraction of the feed, which is later condensed as treated water. Thermal desalination has been the major technique in the early era of desalination 
during the 1950s-1970s [32]. As a rule, thermal desalination stays preferable where: 1) low energy cost, 2) high feedwater salinity and temperature, and 3) co-located with a power plant for power and water production, i.e., cogeneration [33]. Either thermal desalination techniques are through MSF or MED. Seawater is the feed water for almost all MSF plants, and 92\% of MED plants [5].

MSF technique is founded on the flash evaporation of the water portion from feedwater. The heated feedwater (that is to say, seawater flashes below decreased pressure in successive stages) ranges $90^{\circ} \mathrm{C}-120^{\circ} \mathrm{C}[1]$. The brine from the first stage is fed to the following stage, at lower pressure, so that further flashing is happening without an extra supply of heat energy. The vapor formed in each stage is cooled and condensed, while pre-heating the counter-current flowing feedwater, to ameliorate the energy efficiency and economy of MSF. MSF possesses $18 \%$ of the UDC from only 345 plants, i.e., $2 \%$ of the number of desalination plants showing that it is mostly utilized for large-scale plants [5].

MED technique stays more efficient from a thermodynamic point of view juxtaposed to MSF, with greater efficiency ratio and lower energy demands [1]. In MED, the sweater is heated to the boiling temperature in the first effect by means of steam. Brine from the first effect is fed to the second effect, where it is heated by the condensing vapor from the first effect, being at lower pressure, and repeated in a cascade of effects at decreased pressure and temperature [1]. Ameliorations in MED have combined it with vapor compression (VC) to elevate its energy efficiency [1]. MED possesses $7 \%$ of the UDC from almost 900 plants, i.e., $5.6 \%$ of desalination plants [5].

Thermal desalination methods are renowned to be energy-intensive techniques needing both thermal and electrical energy forms [34]. Desalination is very case-specific when it comes to energy consumption, reported as specific energy consumption $\mathrm{kWh} / \mathrm{m}^{3}$ product water. Specific energy consumption is a function of 1) desalination technique, i.e., thermal or membrane, 2) specific technology, i.e., MSF or MED for thermal, RO or NF for membrane, 3) feedwater source or quality, i.e., seawater (SW), brackish water (BW), wastewater (WW), etc., 4) plant design, i.e., design recovery, plant capacity, energy recovery, etc. [35]. MSF plant runs at a temperature $>110^{\circ} \mathrm{C}$ and has reported $3.5 \mathrm{kWh} / \mathrm{m}^{3}$ and $12 \mathrm{kWh} / \mathrm{m}^{3}$ of electrical and thermal energy equivalent, respectively. Relatively, the MED plant runs below $70^{\circ} \mathrm{C}$ and has $1.5 \mathrm{kWh} / \mathrm{m}^{3}$ and $6 \mathrm{kWh} / \mathrm{m}^{3}$, almost half that of MSF [36].

\subsection{Membrane Desalination Methods}

For desalination, membrane methods have been promoted during the 1960s-1970s period, with the major motivations of the augmented energy price [37] [38]. RO remains the primary membrane method, pursued by NF [39]. Osmosis is a natural phenomenon, in which solvent (water in case of desalination) permeates across a semi-permeable membrane (impermeable to the solute) from higher-solvent concentration side of the membrane to the lower-solvent concentra- 
tion, thus forming a differential hydraulic pressure, named osmotic pressure, which continues till hydraulic pressure difference is equal to the osmotic pressure difference across the membrane [1]. Osmotic pressure is a function of the character of solute, the level of solute, and temperature. Seawater has an osmotic pressure of 27 - 30 bars at ambient temperature [40]. In RO desalination, an external hydraulic pressure higher than that of osmotic pressure difference is applied to the saline water to reverse the osmosis phenomenon leading to water extraction from the saline water by permeation through the membrane [1].

$\mathrm{RO}$ desalination was implemented first to brackish groundwater in the late 1960s; then, it was implemented to seawater desalination by the 1980s [32]. Seawater reverse osmosis (SWRO) desalination accounts for 34\% of the UDC, i.e., half of RO desalination, while brackish water desalination (BWD) accounts for $19 \%$ of the UDC, i.e., $27 \%$ of RO desalination as depicted in Figure 2 [5]. RO membranes are frequently fabricated of two different films, active and selective layer or skin, made of polymeric material either cellulose triacetate (CTA) or thin-film composite (TFC) of polyamide (PA), which is in charge of the semi-permeability properties [8] [9] [40]. The second film is a thick support layer to furnish mechanical strength to withstand the high hydraulic pressure that can go up to 70 bars [8] [9]. The driving force for the RO method is the hydraulic pressure applied to overcome the osmotic pressure; therefore, it changes greatly following the feedwater salinity from $15-25$ bar for BWD to $60-70$ bar for SWD [4] [11]. Energy needs vary following the feedwater sources, i.e., brackish water or seawater, with greater energy demands for seawater RO (SWRO) of $2-7 \mathrm{kWh} / \mathrm{m}^{3}$ and less for brackish water RO (BWRO) of $0.4-3 \mathrm{kWh} / \mathrm{m}^{3}$ since it runs at lower pressures [35].

NF membrane was first suggested in the early 1980s to describe a low-pressure RO type of membranes that have a higher rejection of divalent ions relative to that of monovalent ions, with membrane selectivity toward solute of $1 \mathrm{~nm} \mathrm{cu}$ toff, and hence called nano [4]. The NF membranes possess a typical rejection of $60 \%-95 \%$ toward divalent ions, and $10 \%-70 \%$ toward monovalent ions, making it appropriate for a broad set of usages [1]. NF membranes are mostly utilized for the desalination of brackish groundwater and softening of hard water [1]. NF has been employed as an advanced pretreatment of seawater for MSF and RO. NF holds almost 3\% of the UDC, mostly for desalination and softening of BW and RW, as depicted in Figure 2 [5].

\subsection{Emerging Desalination Methods}

In desalination engineering, Research and Development (R\&D) stay highly active because of the towering significance of assuring water supply for human activities. The existing traditional thermal and membrane desalination techniques have attracted considerable expansion endeavors during the decades, attaining a constant maturity degree, with present ameliorations leading to lightweight processes enhancements. In desalination engineering, the following revolution is 
anticipated with the complete expansion of emerging desalination techniques presently at the lab-, pilot-, and small-scale. The motivations for promoting these methods are 1) bigger recovery, 2) lower energy consumption, 3) lower price, 4) large feedwater quality, 5) less EIs, and numerous additional merits [1].

Forward osmosis (FO) is a spontaneous or natural technique that uses the osmosis phenomena; so, it does not require the application of hydraulic pressure [41]. In FO, the normal penchant of solvent (i.e., water) to permeate across the semi-permeable membrane is exploited employing specific higher concentration solutions; thus, bigger osmotic pressure named draw solution. Since FO is a spontaneous method, it is distinguished by lower energy demand, which turns in lower capital and operating costs, with energy consumption as low as 0.25 $\mathrm{kWh} / \mathrm{m}^{3}$ [42]. The first dare retarding the expansion of full-scale FO stays the water extraction from draw solution, which has to be economically and energetically feasible process [1]. The second dare is to promote high water-permeable and selective membranes, with current FO membranes reporting a wide range of $1-81 \mathrm{~L} / \mathrm{m}^{2} \mathrm{~h}$ pure water permeability, following the membrane material and draw solution [43].

Electrodialysis/electrodialysis reversal (ED/EDR) desalination has been proposed since the 1950s and employs electrical potential to allow the electrochemical separation of ions [1]. Lately, ED/EDR has attracted notice thanks to ameliorations in electrode material for low salinity feedwater desalination like BWD and pure water treatment [1], or high-salinity brine for brine concentration or minimization [1]. ED/EDR possesses the benefit of using higher suspended and dissolved solid contents feedwater, i.e., high fouling tolerance, higher recovery, and higher durability [1]. ED/EDR possesses a share of around $2 \%$ of the UDC, with $60 \%$ for BWD and $20 \%$ for RW [5]. Energy consumption stays a crucial parameter in ED/EDR operation; with BWD of $7-8 \mathrm{mS} / \mathrm{cm}$ salinity consumes 1 $\mathrm{kWh} / \mathrm{m}^{3}$ while the concentration of SWRO brine from $60 \mathrm{~g} / \mathrm{L}$ to $200 \mathrm{~g} / \mathrm{L}$ has an energy consumption of $3.7 \mathrm{kWh} / \mathrm{m}^{3}$ [1].

Membrane distillation (MD) is merely an integration of thermal and membrane desalination and is mostly a thermal-driven technique [42]. In MD, feedwater is heated below boiling temperature to give off a vapor that permeates across a hydrophobic membrane that lets only water vapor, but not liquid, which is then condensed and collected as a product [44]. MD technology implies merged heat and mass transfer and happens at ambient pressure, in the span of $70^{\circ} \mathrm{C}-90^{\circ} \mathrm{C}[1]$. MD possesses the benefits of 1 ) total solute rejection; 2) recovery and the energy consumption are not a function of feed salinity; 3) high concentration factor, theoretically up to saturation and; 4) no external pressure, so minimal fouling [45].

Capacitive deionization (CDI) is identical to ED/EDR, since it employs electrical potential as a driving force for attracting iconic species, but utilizing electrosorption of ions into the electrode surface [46]. As for ED/EDR, most of the $\mathrm{R} \& \mathrm{D}$ attempts in CDI are to present fresh electrode material with an elevated ca- 
pability, lately concentrating on using new graphene-founded material [1] [47].

Adsorption desalination (AD) is so identical to MD in theory, with the distinction of utilizing adsorbent material, like silica gel, rather than a membrane, during adsorption cycle; then, water is stripped or desorbed during desorption cycle [1] [48].

Freezing desalination (FD) is one more emerging desalination technique that possesses identical merits to that of $\mathrm{MD}$ and $\mathrm{AD}$ [49]. In FD, saline water is cooled down to freeze water as ice, which is separated in a solid-liquid separator, leaving a brine solution [50]. Lately, more regard has been accorded to FD thanks to the evolving in the liquefied natural gas (LNG) industry, which could be employed as cryogenic fluid to drive FD [1].

\section{Environmental Impacts (EIs) of Desalination}

Desalination has progressed as a credible solution to the dare of secured water supply to numerous underserved nations worldwide. Technology has greatly advanced during the decades, rendering it both economically and technically practical method. While the great value desalination provides to humankind, furnishing the vital water supply, it has been related to several influences on nature. The EIs linked to desalination could be abstracted as follow in association with each stage in the desalination train from feedwater intake to brine disposal:

- Indeed, Figure 3 illustrates a clear schematic of the inputs and outputs to the desalination technology and its interaction with nature [1].

- Further, Figure 4 shows the interrelations between the desalination process parameters and relative EIs [1].

\section{Environmental Impacts (EIs) of the Brine Disposal and Their Control}

\subsection{Environmental Impacts (EIs) of the Brine Disposal}

In terms of qualitative and quantitative criteria, desalination brine remains a

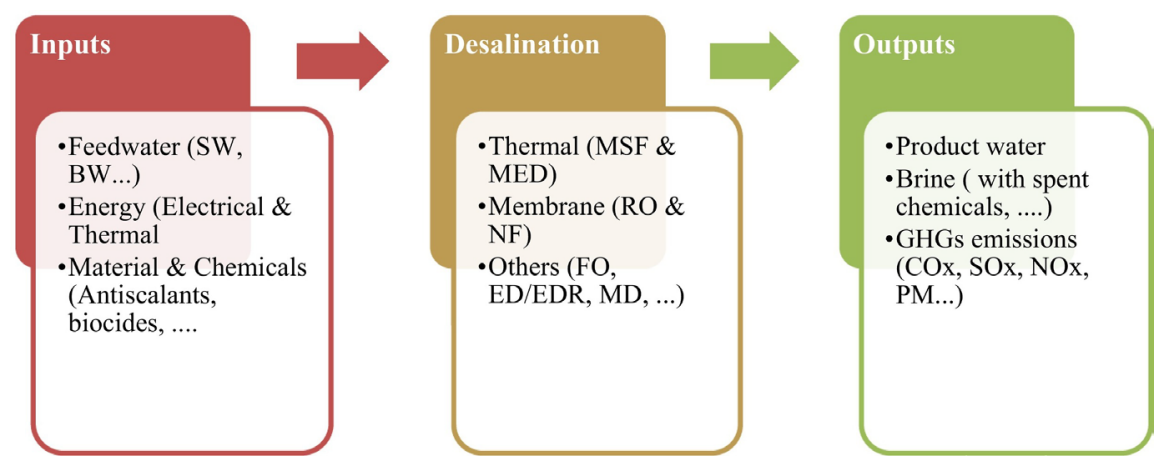

Figure 3. Schematic of desalination technology inputs and outputs $(\mathrm{RO}=$ reverse osmosis, $\mathrm{MSF}=$ multi-stage flash distillation, $\mathrm{MED}=$ multi-effect distillation, NF $=$ nanofiltration, $\mathrm{ED} / \mathrm{EDR}=$ electrodialysis/electrodialysis reversal, $\mathrm{SW}=$ seawater, $\mathrm{BW}=$ brackish water, $\mathrm{FO}=$ forward osmosis, $\mathrm{MD}=$ membrane distillation, GHGs =greenhouse gases) $[1]$. 


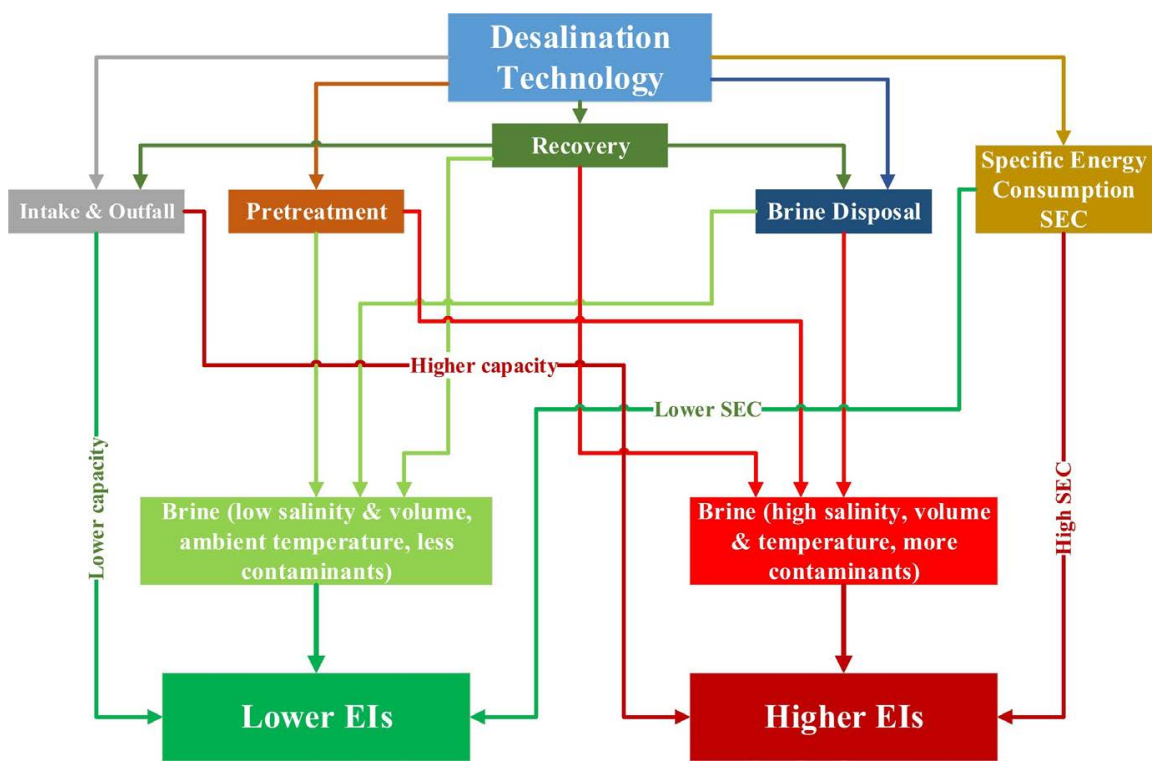

Figure 4. Interrelations among the desalination process parameters and relative environmental impacts (EIs) (Specific energy consumption, SEC) [1].

huge waste stream [1]. The ratio of brine to feed could vary from $1-2$ for SWRO to 5 - 8 for thermal desalination that possesses a considerable impact on the marine environment at the point of discharge [1]. Linked to brine disposal, the EIs stay mostly affected by the next parameters: salinity, temperature, $\mathrm{pH}$, residual chemicals, reactions by-products, and heavy metals [51]. The brine salinity and temperature are viewed as the main factors to touch the marine environment since brine salinity could attain $65-85 \mathrm{~g} / \mathrm{L}$ and temperature $45^{\circ} \mathrm{C}-50^{\circ} \mathrm{C}$ [52]. The additional important EI of brine is related to a load of chemical products injected during pretreatment like biocides and biocide scavengers as well as disinfection by-products, which provoke considerable ecotoxicity [53] [54] [55]. Coagulants like aluminum sulfate (alum) [56] [57] [58] and ferric chloride [59] [60] [61] and flocculants [62] [63] [64] are introduced during pretreatment to eliminate suspended and much dispersed solids [65] [66] [67], which end up with filter backwash to be disposed of with brine stream [1]. Antiscalant is injected to dominate scaling due to sparingly soluble salts, thus keep plant productivity, especially at elevated recovery [1]. The brine could carry traces of heavy metals (like copper, chromium, nickel, iron, molybdenum, etc.) as corrosion products of metals employed with corrosion formed by high feedwater salinity [1].

\subsection{Mitigation and Control of the EIs of the Brine Disposal}

Brine disposal constitutes the closing interaction with nature through brine outfall. The properties of brine to be removed from desalination plant are interconnected to additional plant components (like intake and outfall, pretreatment, and desalination technology). For brine disposal, the definitive M\&CSs remain the elimination of the necessity for brine disposal for SWRO seawater, and most 
importantly, for BWRO through zero liquid discharge (ZLD) process [1] [25] [68]. In ZLD, more water is recuperated, and crucial solid salt is left that could be of beneficial uses or as feed for other plants such as for table salt production, chlorine, and caustic soda [1]. The second solution is to diminish the volume of the brine stream via merging hybrid desalination systems like ED/EDR, which could augment the brine level from $60 \mathrm{~g} / \mathrm{L}$ to $200 \mathrm{~g} / \mathrm{L}$ so decreasing the brine volume by almost $2 / 3$ [30].

Table 1 resumes the M\&CS for the EIs related to brine disposal. It is worth mentioning that some of the M\&CSs are utilized for some other desalination plant components like intake and outfall because of their mutual impact [1].

\section{Conclusion}

In this work, we presented general recommendations to reduce the whole EIs of desalination engineering, with some successful situations to establish the performance of these M\&Cs strategies especially those for brine disposal. We also discussed the main improvements in the field of desalination engineering. From this review, the following observations and conclusions arose:

1) Desalination has a vital contribution to safeguarding human life since it resolves the dare of water supply, especially for water-scarce regions. Desalination remains the first water source for numerous nations like in GCC countries, presenting $>90 \%$ of domestic water supply. Thermal and membrane desalination techniques have nearly attained maturity degrees with established technical and economic feasibility [1]. Fresh desalination techniques are presently below expansion with greater productivity and energy efficiency compared to actual

Table 1. M\&CSs for the EIs related to brine disposal [1].

\begin{tabular}{|c|c|c|}
\hline Parameters & Environmental impacts (EIs) & $\begin{array}{l}\text { Mitigation \& control } \\
\text { strategies (M\&CSs) }\end{array}$ \\
\hline $\begin{array}{l}\text { Pretreatment chemicals } \\
\text { \& heavy metals }\end{array}$ & $\begin{array}{l}\text { - Increase salinity and temperature of water } \\
\text { - } \text { Cody at the discharge point. } \\
\text { - Increase the salinity of groundwater aqui- } \\
\text { fer. } \\
\text { - Salinity increase of sediments. } \\
\text { - Reduce oxygen solubility and content. } \\
\text { - Increase mortality of aquatic life. } \\
\text { - Change the structure of the benthic } \\
\text { community. } \\
\text { - Change in aquatic diversity. } \\
\text { - Change the photosynthesis, metabolic, } \\
\text { - Formd growth rates. } \\
\text { - Introduce foreign chemicals. } \\
\text { - Increase water turbidity. } \\
\text { - Water discoloration due to metal salts } \\
\text { added during pretreatment. } \\
\text { - Contamination of groundwater aquifer. }\end{array}$ & $\begin{array}{l}\text { - Apply ZLD technologies. } \\
\text { - } \text { High recovery desalination. } \\
\text { - } \text { Brine pre-dilution with } \\
\text { wastewater and cooling } \\
\text { water. } \\
\text { - } \text { Efficient pretreatment. } \\
\text { - } \text { Use subsurface intake. } \\
\text { - } \text { Use of high-quality } \\
\text { materials. } \\
\text { - Proper maintenance plan. } \\
\text { - Brine treatment for } \\
\text { removal of toxic } \\
\text { components. } \\
\text { - Place outfall in an active } \\
\text { hydrodynamic area with } \\
\text { high currents. }\end{array}$ \\
\hline
\end{tabular}


desalination technologies. Nevertheless, desalination generates several environmental impacts (EIs) that should be cautiously dominated.

2) For the numerous EIs related to desalination, mitigation and control strategies (M\&CSs) ones are more than important [1]. In this review, we have mainly examined the M\&CS for brine disposal. Feedwater source and quality, desalination engineering, and energy source were established to possess an essential influence on the general desalination's EIs. Choosing conveniently the desalination technique stays the central part for reducing the general EIs. Indeed, the desalination technique dictates intake and outfall size, pretreatment demand, energy consumption, and volume of brine disposed of. Mixed desalination technologies, emerging desalination techniques, and employing renewable energies are established to greatly diminish the desalination EIs and viewed as strong M\&CSs tools.

\section{Acknowledgements}

The Research Deanship of University of Ha'il, Saudi Arabia, through the Project RG-20113, has funded this research.

\section{Conflicts of Interest}

The author declares no conflicts of interest regarding the publication of this paper.

\section{References}

[1] Elsaid, K., Sayed, E.T., Abdelkareem, M.A., Baroutaji, A., and Olabi, A.G. (2020) Environmental Impact of Desalination Processes: Mitigation and Control Strategies. Science of the Total Environment, 740, Article ID: 140125. https://doi.org/10.1016/j.scitotenv.2020.140125

[2] Ghernaout, D. (2017) Environmental Principles in the Holy Koran and the Sayings of the Prophet Muhammad. American Journal of Environmental Protection, 6, 75-79. https://doi.org/10.11648/j.ajep.20170603.13

[3] Ghernaout, D. (2013) The Best Available Technology of Water/Wastewater Treatment and Seawater Desalination: Simulation of the Open Sky Seawater Distillation. Green and Sustainable Chemistry, 3, 68-88. https://doi.org/10.4236/gsc.2013.32012

[4] Fritzmann, C., Löwenberg, J., Wintgens, T. and Melin, T. (2007) State-of-the-Art of Reverse Osmosis Desalination. Desalination, 216, 1-76.

https://doi.org/10.1016/j.desal.2006.12.009

[5] Jones, E., Qadir, M., van Vliet, M.T.H., Smakhtin, V. and Kang, S. (2019) The State of Desalination and Brine Production: A Global Outlook. Science of The Total Environment, 657, 1343-1356. https://doi.org/10.1016/j.scitotenv.2018.12.076

[6] Irki, S., Kasbadji-Merzouk, N., Hanini, S. and Ghernaout, D.(2020) Modelling of the Coupling of Desalination Plants with the Thermal Solar Energy System. Water Supply, 20, 1807-1822. https://doi.org/10.2166/ws.2020.092

[7] Singh, Y.B. and Ng, K.C. (2019) Elucidation of Dual-Mode Inhibition Mechanism of a Typical Polymer-Based Antiscalant on Red Seawater for Thermal Desalination at Higher Temperatures and Higher Concentration Factors. Journal of Petroleum Science and Engineering, 183, Article ID: 106380. 
https://doi.org/10.1016/j.petrol.2019.106380

[8] Ghernaout, D. and El-Wakil, A. (2017) Requiring Reverse Osmosis Membranes Modifications-An Overview. American Journal of Chemical Engineering, 5, 81-88. https://doi.org/10.11648/j.ajche.20170504.15

[9] Ghernaout, D. (2017) Reverse Osmosis Process Membranes Modeling-A Historical Overview. Journal of Civil, Construction and Environmental Engineering, 2, 112-122.

[10] Ghernaout, D., Alshammari, Y., Alghamdi, A., Aichouni, M., Touahmia, M. and Ait, Messaoudene, N. (2018) Water Reuse: Extenuating Membrane Fouling in Membrane Processes. American Journal of Chemical Engineering, 6, 25-36. https://doi.org/10.11648/j.ajche.20180602.12

[11] Malaeb, L. and Ayoub, G.M. (2011) Reverse Osmosis Technology for Water Treatment: State of the Art Review. Desalination, 267, 1-8.

https://doi.org/10.1016/j.desal.2010.09.001

[12] Son, H.S., Shahzad, M.W., Ghaffour, N. and Ng, K.C. (2020) Pilot Studies on Synergetic Impacts of Energy Utilization in Hybrid Desalination System: Multi-Effect Distillation and Adsorption Cycle (MED-AD). Desalination, 477, Article ID: 114266. https://doi.org/10.1016/j.desal.2019.114266

[13] Ghernaout, D. (2019) Brine Recycling: Towards Membrane Processes as the Best Available Technology. Applied Engineering, 3, 71-84.

[14] Park, K., Kim, J., Yang, D.R and Hong, S. (2020) Towards a Low-Energy Seawater Reverse Osmosis Desalination Plant: A Review and Theoretical Analysis for Future Directions. Journal of Membrane Science, 595, Article ID: 117607. https://doi.org/10.1016/j.memsci.2019.117607

[15] Swaminathan, J., Tow, E.W., Stover, R.L. and Lienhard, J.H. (2019) Practical Aspects of Batch RO Design for Energy-Efficient Seawater Desalination. Desalination, 470, Article ID: 114097. https://doi.org/10.1016/j.desal.2019.114097

[16] Yusuf, A., Sodiq, A., Giwa, A., Eke, J., Pikuda, O., De Luca, G., Di Salvo, J.L. and Chakraborty, S. (2020) A Review of Emerging Trends in Membrane Science and Technology for Sustainable Water Treatment. Journal of Cleaner Production, 266, Article ID: 121867. https://doi.org/10.1016/j.jclepro.2020.121867

[17] Roy, K., Mukherjee, A., Maddela, N.R, Chakraborty, S., Shen, B., Li, M., Du, D., Peng, Y., Lu, F. and Garciá Cruzatty, L.C. (2020) Outlook on the Bottleneck of Carbon Nanotube in Desalination and Membrane-Based Water Treatment-A Review. Journal of Environmental Chemical Engineering, 8, Article ID: 103572. https://doi.org/10.1016/j.jece.2019.103572

[18] Elimelech, M. and Phillip, W.A. (2011) The Future of Seawater Desalination: Energy, Technology, and the Environment. Science, 333, 712-717. https://doi.org/10.1126/science.1200488

[19] Kress, N. and Galil, B. (2018) Impact of Seawater Desalination by Reverse Osmosis on the Marine Environment. In: Kress, N. and Galil, B., Eds., Efficient Desalination by Reverse Osmosis, IWA Publishing, London.

[20] Lu, K.J., Cheng, Z.L., Chang, J., Luo, L. and Chung, T.S. (2019) Design of Zero Liquid Discharge Desalination (ZLDD) Systems Consisting of Freeze Desalination, Membrane Distillation, and Crystallization Powered by Green Energies. Desalination, 458, 66-75. https://doi.org/10.1016/j.desal.2019.02.001

[21] Mezher, T., Fath, H., Abbas, Z. and Khaled, A. (2011) Techno-Economic Assessment and Environmental Impacts of Desalination Technologies. Desalination, 266, 263-273. https://doi.org/10.1016/j.desal.2010.08.035 
[22] Hoepner, T. (1999) A Procedure for Environmental Impact Assessments (EIA) for Seawater Desalination Plants. Desalination, 124, 1-12. https://doi.org/10.1016/S0011-9164(99)00083-1

[23] Kress, N. (2019) Marine Environmental Impact of Seawater Desalination: Science, Management, and Policy. Elsevier Inc., Amsterdam.

[24] Alshahri, A.H., Fortunato, L., Ghaffour, N. and Leiknes, T.O (2019)Advanced Coagulation Using in-situ Generated Liquid Ferrate, Fe (VI), for Enhanced Pretreatment in Seawater RO Desalination during Algal Blooms. Science of the Total Environment, 685, 1193-1200. https://doi.org/10.1016/j.scitotenv.2019.06.286

[25] Giwa, A., Dufour, V., Al Marzooqi, F., Al Kaabi, M. and Hasan, S.W. (2017) Brine Management Methods: Recent Innovations and Current Status. Desalination, 407, 1-23. https://doi.org/10.1016/j.desal.2016.12.008

[26] Hashim, A. and Hajjaj, M. (2005) Impact of Desalination Plants Fluid Effluents on the Integrity of Seawater, with the Arabian Gulf in Perspective. Desalination, 182, 373-393. https://doi.org/10.1016/j.desal.2005.04.020

[27] Mavukkandy, M.O., Chabib, C.M., Mustafa, I., Al Ghaferi, A. and AlMarzooqi, F. (2019) Brine Management in Desalination Industry: From Waste to Resources Generation. Desalination, 472, Article ID: 114187. https://doi.org/10.1016/j.desal.2019.114187

[28] Ameen, F., Stagner, J.A. and Ting, D.S.K. (2018) The Carbon Footprint and Environmental Impact Assessment of Desalination. International Journal of Environmental Studies, 75, 45-58. https://doi.org/10.1080/00207233.2017.1389567

[29] Abdelkareem, M.A., El Haj Assad, M., Sayed, E.T. and Soudan, B. (2018) Recent Progress in the Use of Renewable Energy Sources to Power Water Desalination Plants. Desalination, 435, 97-113. https://doi.org/10.1016/j.desal.2017.11.018

[30] Panagopoulos, A., Haralambous, K.J. and Loizidou, M. (2019) Desalination Brine Disposal Methods and Treatment Technologies-A Review. Science of the Total Environment, 693, Article ID: 133545.

https://doi.org/10.1016/j.scitotenv.2019.07.351

[31] Choi, J., Oh, Y., Chae, S. and Hong, S. (2019) Membrane Capacitive Deionization-Reverse Electrodialysis Hybrid System for Improving Energy Efficiency of Reverse Osmosis Seawater Desalination. Desalination, 462, 19-28. https://doi.org/10.1016/j.desal.2019.04.003

[32] Van der Bruggen, B. and Vandecasteele, C. (2002) Distillation vs. Membrane Filtration: Overview of Process Evolutions in Seawater Desalination. Desalination, 143, 207-218. https://doi.org/10.1016/S0011-9164(02)00259-X

[33] Mabrouk, A.N. and Fath, H.E.S. (2015) Technoeconomic Study of a Novel Integrated Thermal MSF-MED Desalination Technology. Desalination, 371, 115-125. https://doi.org/10.1016/j.desal.2015.05.025

[34] Tarnacki, K., Meneses, M., Melin, T., van Medevoort, J. and Jansen, A. (2012) Environmental Assessment of Desalination Processes: Reverse Osmosis and Memstill ${ }^{\oplus}$. Desalination, 296, 69-80. https://doi.org/10.1016/j.desal.2012.04.009

[35] Ghalavand, Y., Hatamipour, M.S. and Rahimi, A. (2015) A Review on Energy Consumption of Desalination Processes. Desalination and Water Treatment, 54, 1526-1541.

[36] Lattemann, S. and Höpner, T. (2008) Environmental Impact and Impact Assessment of Seawater Desalination. Desalination, 220, 1-15.

https://doi.org/10.1016/j.desal.2007.03.009 
[37] Greenlee, L.F., Lawler, D.F., Freeman, B.D., Marrot, B. and Moulin, P. (2009) Reverse Osmosis Desalination: Water Sources, Technology, and Today's Challenges. Water Research, 43, 2317-2348. https://doi.org/10.1016/j.watres.2009.03.010

[38] Ghernaout, D., El-Wakil, A., Alghamdi, A., Elboughdiri, N. and Mahjoubi, A. (2018) Membrane Post-Synthesis Modifications and How it Came about. International Journal of Advances in Applied Sciences, 5, 60-64. https://doi.org/10.21833/ijaas.2018.02.010

[39] Ghernaout, D. (2020) New Configurations and Techniques for Controlling Membrane Bioreactor (MBR) Fouling. Open Access Library Journal, 7, e6579.

[40] Qasim, M., Badrelzaman, M., Darwish, N.N., Darwish, N.A. and Hilal, N. (2019) Reverse Osmosis Desalination: A State-of-the-Art Review. Desalination, 459, 59-104. https://doi.org/10.1016/j.desal.2019.02.008

[41] Ang, W.L., Mohammad, A.W., Johnson, D. and Hilal, N. (2020) Unlocking the Application Potential of Forward Osmosis through Integrated/Hybrid Process. Science of the Total Environment, 706, Article ID: 136047. https://doi.org/10.1016/j.scitotenv.2019.136047

[42] Subramani, A. and Jacangelo, J.G. (2015) Emerging Desalination Technologies for Water Treatment: A Critical Review. Water Research, 75, 164-187. https://doi.org/10.1016/j.watres.2015.02.032

[43] Darwish, M.A., Abdulrahim, H.K., Hassan, A.S., Mabrouk, A.A. and Sharif, A.O. (2016) The Forward Osmosis and Desalination. Desalination and Water Treatment, 57, 4269-4295. https://doi.org/10.1080/19443994.2015.1066270

[44] González, D., Amigo, J. and Suárez, F. (2017) Membrane Distillation: Perspectives for Sustainable and Improved Desalination. Renewable and Sustainable Energy Review, 80, 238-259. https://doi.org/10.1016/j.rser.2017.05.078

[45] Sanmartino, J.A., Khayet, M. and García-Payo, M.C. (2016) Desalination by Membrane Distillation. In: Hankins, N.P. and Singh, R., Eds., Emerging Membrane Technology for Sustainable Water Treatment, Elsevier B.V., Amsterdam, 77-109. https://doi.org/10.1016/B978-0-444-63312-5.00004-8

[46] AlMarzooqi, F.A., Al Ghaferi, A.A., Saadat, I. and Hilal, N. (2014) Application of Capacitive Deionisation in Water Desalination: A Review. Desalination, 342, 3-15. https://doi.org/10.1016/j.desal.2014.02.031

[47] Moustafa, H.M., Obaid, M., Nassar, N.M., Abdelkareem, M.A. and Mahmoud, M.S. (2020) Titanium Dioxide-Decorated rGO as an Effective Electrode for Ultrahigh-Performance Capacitive Deionization. Separation and Purification Technology, 235, Article ID: 116178. https://doi.org/10.1016/j.seppur.2019.116178

[48] Ng, K.C., Thu, K., Kim, Y., Chakraborty, A. and Amy, G. (2013) Adsorption Desalination: An Emerging Low-Cost Thermal Desalination Method. Desalination, 308, 161-179. https://doi.org/10.1016/j.desal.2012.07.030

[49] Williams, P.M., Ahmad, M. and Connolly, B.S. (2013) Freeze Desalination: An Assessment of an Ice Maker Machine for Desalting Brines. Desalination, 308, 219-224. https://doi.org/10.1016/j.desal.2012.07.037

[50] Kalista, B., Shin, H., Cho, J. and Jang, A. (2018) Current Development and Future Prospect Review of Freeze Desalination. Desalination, 447, 167-181. https://doi.org/10.1016/j.desal.2018.09.009

[51] Mannan, M., Alhaj, M., Mabrouk, A.N. and Al-Ghamdi, S.G. (2019) Examining the Life-Cycle Environmental Impacts of Desalination: A Case Study in the State of Qatar. Desalination, 452, 238-246. https://doi.org/10.1016/j.desal.2018.11.017 
[52] Alharbi, O.A., Phillips, M.R., Williams, A.T., Gheith, A.M., Bantan, R.A. and Rasul, N.M. (2012) Desalination Impacts on the Coastal Environment: Ash Shuqayq, Saudi Arabia. Science of the Total Environment, 421-422, 163-172. https://doi.org/10.1016/j.scitotenv.2012.01.050

[53] Ghernaout, D., Elboughdiri, N. and Al Arni, S. (2020) New Insights towards Disinfecting Viruses-Short Notes. Journal of Water Reuse and Desalination, London. https://doi.org/10.2166/wrd.2020.050

[54] Ghernaout, D. (2020) Demobilizing Antibiotic-Resistant Bacteria and Antibiotic Resistance Genes by Electrochemical Technology: New insights. Open Access Library Journal, 7, 1-18. https://doi.org/10.4236/oalib.1106685

[55] Ghernaout, D. (2020) Electric field (EF) in the Core of the Electrochemical (EC) Disinfection. Open Access Library Journal, 7, 1-20.

[56] Ghernaout, D., Ghernaout, B., Saiba, A., Boucherit, A. and Kellil, A. (2009) Removal of Humic Acids by Continuous Electromagnetic Treatment Followed by Electrocoagulation in Batch Using Aluminium Electrodes. Desalination, 239, 295-308. https://doi.org/10.1016/j.desal.2008.04.001

[57] Ghernaout, D., Ghernaout, B., Boucherit, A., Naceur, M.W., Khelifa, A. and Kellil, A. (2009) Study on Mechanism of Electrocoagulation with Iron Electrodes in Idealised Conditions and Electrocoagulation of Humic Acids Solution in Batch Using Aluminium Electrodes. Desalination and Water Treatment, 8, 91-99. https://doi.org/10.5004/dwt.2009.668

[58] Ghernaout, D., Al-Ghonamy, A.I., Ait Messaoudene, N., Aichouni, M., Naceur, M.W., Benchelighem, F.Z. and Boucherit, A. (2015) Electrocoagulation of Direct Brown 2 (DB) and BF Cibacete Blue (CB) Using Aluminum Electrodes. Separation Science and Technology, 50, 1413-1420. https://doi.org/10.1080/01496395.2014.982763

[59] Ghernaout, D., Laribi, C., Alghamdi, A., Ghernaout, B., Ait Messaoudene, N. and Aichouni, M. (2018) Decolorization of BF Cibacete Blue (CB) and Red Solophenyle 3BL (RS) Using Aluminum Sulfate and Ferric Chloride. World Journal of Applied Chemistry, 3, 32-40. https://doi.org/10.11648/j.wjac.20180302.11

[60] Irki, S., Ghernaout, D., Naceur, M.W., Alghamdi, A. and Aichouni, M. (2018) Decolorization of Methyl Orange (MO) by Electrocoagulation (EC) Using Iron Electrodes under a Magnetic Field (MF). II. Effect of Connection Mode. World Journal of Applied Chemistry, 3, 56-64. https://doi.org/10.11648/j.wjac.20180302.13

[61] Ghernaout, D. and Elboughdiri, N. (2019) Iron Electrocoagulation Process for Disinfecting Water-A Review. Applied Engineering, 3, 154-158.

[62] Ghernaout, B., Ghernaout, D. and Saiba, A. (2010) Algae and Cyanotoxins Removal by Coagulation/Flocculation: A Review. Desalination and Water Treatment, 20, 133-143. https://doi.org/10.5004/dwt.2010.1202

[63] Ghernaout, D. and Ghernaout, B. (2012) Sweep Flocculation as a Second Form of Charge Neutralisation-A Review. Desalination and Water Treatment, 44, 15-28. https://doi.org/10.1080/19443994.2012.691699

[64] Ghernaout, D., Irki, S. and Boucherit, A. (2014) Removal of $\mathrm{Cu}^{2+}$ and $\mathrm{Cd}^{2+}$, and Humic Acid and Phenol by Electrocoagulation Using Iron Electrodes. Desalination and Water Treatment, 52, 3256-3270. https://doi.org/10.1080/19443994.2013.852484

[65] Ghernaout, D., Al-Ghonamy, A.I., Naceur, M.W., Boucherit, A., Messaoudene, N.A., Aichouni, M., Mahjoubi, A.A. and Elboughdiri, N.A. (2015) Controlling Coagulation Process: From Zeta Potential to Streaming Potential. American Journal 
of Environmental Protection, 4, 16-27.

https://doi.org/10.11648/j.ajeps.s.2015040501.12

[66] Ghernaout, D., Badis, A., Braikia, G., Matâam, N., Fekhar, M., Ghernaout, B. and Boucherit, A. (2017) Enhanced Coagulation for Algae Removal in a Typical Algeria Water Treatment Plant. Environmental Engineering and Management Journal, 16, 2303-2315. https://doi.org/10.30638/eemj.2017.238

[67] Irki, S., Ghernaout, D. and Naceur, M.W. (2017) Decolourization of Methyl Orange (MO) by Electrocoagulation (EC) Using iron Electrodes under a Magnetic Field (MF). Desalination and Water Treatment, 79, 368-377.

https://doi.org/10.5004/dwt.2017.20797

[68] Yaqub, M. and Lee, W. (2019) Zero-Liquid Discharge (ZLD) Technology for Resource Recovery from Wastewater: A Review. Science of the Total Environment, 681, 551-563. https://doi.org/10.1016/j.scitotenv.2019.05.062 